\title{
The Effect of Using Simulation on Developing Students' Character Education in Learning Economics
}

\section{Fahimul Amri}

Dr. candidate, Economics Education, Universitas Negeri Malang, Indonesia, fahimul.amri@gmail.com

\section{Ery Tri Djatmika}

Economics Education, Universitas Negeri Malang, Indonesia, ery.tri.fe@um.ac.id

\section{Hari Wahyono}

Economics Education, Universitas Negeri Malang, Indonesia, hari.wahyono.fe@um.ac.id

Sri Umi Mintarti Widjaja

Economics Education, Universitas Negeri Malang, , Indonesia, sri.umi.fe@um.ac.id

This research aims to explain the effect in using simulation to develop students' educated character in learning economics. The quantitative analysis uses pre- and post-test experimental design, while descriptive analysis is completed with percentage analysis and the category of the mean score. Instruments of data collection use observation rule and questionnaire by using four scale assessments start from very good/strongly agree until very bad/strongly disagree. The result of the research shows that there are different characters in education development before and after implementation simulation in learning economics. The use of simulation in learning economics has an effect on the development of student character education. The simulation in learning economics can develop the students' character with very good category, with a total percentage that shows the number of good at $56.29 \%$ and very good at $42.71 \%$. Through simulation, learning economics conducted is easier to develop the very important character education in students' life. The simulation which presents the real situation in learning economics improves the students' learning experience in economics field, so that the students can feel that real condition, especially for learning activity to do the economical activity by implementing good characters (by using good ways) and avoids the bad ways which can be harmful for others.

Keywords: simulation, character education, learning economics, students, students' educated character

Citation: Amri, F., Djatmika, E. T., Wahyono, H., \& Widjaja, S. U. M. (2020). The Effect of Using Simulation on Developing Students' Character Education in Learning Economics. International Journal of Instruction, 13(4), 375-392. https://doi.org/10.29333/iji.2020.13424a 


\section{INTRODUCTION}

Character education has been discussed by experts, including in the economic field. Character education has been recognized as part of moral education. Even some opinions have mentioned that the character education is also called as moral education or value education (Berkowitz, 2011; Ho et al., 2013). Character education has become essential part in developing education and it becomes the strategic policy agenda in education in the world (Narvaez \& Lapsley, 2008; Arweck et al., 2005). The character education has been developed in some countries, such as in Swedia and Turkey (Thornberg \& Oguz, 2016; Beldağ, 2016), in England (Revell \& Arthur, 2007; Arthur \& Carr, 2013), in Portugal (Lopes et al., 2013), in America (Martinson, 2003; Revell, 2002), in Mexico (Tatto et al., 2001), in Taiwan (Lee, 2009; Ho et al., 2013), and in Malaysia (Haslip \& Haslip, 2013).

The education character has become strategic agenda in developing education in Indonesia (Hakam, 2018). The education in Indonesia has experienced a big change, signed with the Act No 20 year 2003 about national educational system Indonesia (Suyatno et al., 2019). The rule becomes one of the basics for character education development in all education fields. The character education development is also strengthened with the minister of education and culture Act No 20 in 2018 about strengthening character education in formal education units. Through the rule, it has become the developing of character education for students at school.

The stronger development in character education in all educational level has had background with the problems faced by Indonesia namely corruption. The corruption problem has damaged the joints of Indonesian life. One of the efforts which have been done by the educational constitution takers to prevent the developing corruption and other prolems is through the character education development to the students who are still learning at school. The program of character education development for the students have been conducted by the schools is honesty canteen. The program has aimed to embed the honesty early for students at school however the program has failed and it is shown by the loss profit managed by schools (Amri, 2018) even the honesty canteen has shown the bad economical behavior done by the students (Amri et al., 2019). So that the program of honesty canteen has given less impact in strengthening character education development for students at school, especially for the students who are learning economics.

The program of strengthening character education development which has not integrated in each learning process and learning material makes the program of character education field done has failed (Bahri, 2015; Amri, 2018). Therefore the character education development must be able to integrate in all lessons and can be implemented in various educational levels (Hakam 2018; Kuh \& Umbach, 2004; Novianti, 2017). However, the fact shows that the character education development through integration in learning process still meets the obstacles. One of the obstacles is caused by the method or learning strategy used by the teachers has not been right so that the teacher feels difficult in integrating character education in learning process in class (Almerico, 2014; Lee, 2009; Nurdin, 2015; Zurqoni et al., 2018a). The learning approach which can be used in 
integrating character education in learning process has constructivistic approach with students centered (Hakam, 2018), as in using cooperative learning which contains the character values (Brannon, 2008; Lickona, 1999; Matchett, 2009), and game learning, simulation, and role play that are able to show the interaction among students (Chowdhury, 2016; Thornberg \& Oguz, 2016).

Economics education taught at schools cannot be separated from the character education, because the social study in the economics field gives the chance to develop the goodness and character (Milson, 2002). The character development can become the essential component in education in social study in economics field in many cases which has the same aim (Milson, 2002). Character education becomes the part of learning economics process done by the teacher at school. The implementation of character education in learning economics will give students' experience in doing daily economical activity, so that the economical activity done can give goodness for themselves and others (Peterson \& Seligman, 2004). Therefore the character education development is implemented in learning economic by using learning model with students centered, namely simulation. The simulation in this research is used to develop student character education in economics. The simulation in this research revealed the economic activities carried out in good ways and those carried out in bad ways. Simulation through the use of role play (Gillentine \& Schulz, 2001; Merideth \&Yaseen, 2000; DeNeve \& Heppner, 1997), so that the simulation can be done easily, fun, and students can understand the values of good characters in economic activities.

Based on the results of previous studies indicate that there has not been specifically revealed the development of student character education in learning economics, including the development of student character in learning economics by using simulation. So through this research has shown the development of student character education in learning economics by using simulation. This research question what is the effect of using simulation in learning economics on the development of student character education?. The aim of this study is to explain the effect of using simulation in learning economics in developing students' character education.

\section{LITERATURE REVIEW}

\section{Simulation}

Simulation is the pedagogic technique and strategy which is similar with role play, sosiodrama, psychodrama, game, and reflection activity done by imitating real world phenomena through interactional process to strengthen self confidence, real experience, and also strengthen the knowledge and the skill got by the students (Betts et al., 2009). The simulation is also called as teaching method which reflects the actual situation through the use of game, scenario, role play, and socio-drama (Gillentine \& Schulz, 2001; Ganesh \& Sun, 2009).

The simulation can be used to show to the students about the scientific phenomena which cannot be observed easily in real time (Scalise et al., 2011). Learning technique in simulation role play is the active, innovative, and effective learning to achieve specific purpose, such as application for real world problem so that it can develop the students' 
interest and it helps the students to implement the material in real world situation (DeNeve \& Heppner, 1997). The simulation learning is very effective and interactive learning experience in imaging real condition of phenomena both physics and social life (Ruiz et al., 2014). The activity done by inputting the real world to be imitated or simplified and performed in class so that the activity can improve the knowledge learnt and improve the skill in students' real life (Roux \& Steyn, 2007; Seel \& Blumschein, 2009). McKeachie (1986) also mentions that the simulation gives model that some problematic lives into real life in class.

Active learning method as simulation helps the students to implement the concept learnt in class in real world situation and can improve the ability in solving problem (Ganesh \& Sun, 2009). The simulation is an active learning method which can improve the students' involvement and give them chance to participate in real world through concrete experience, namely through observing and reflecting process so that it can be useful in improving students' learning experience (Marriott et al., 2015). The important thing in simulation is when the students get failure and do not have any consequence in the real world (Zapalska \& Brozik, 2008).

Besides learning with experience based such as simulation, game, and role play teaches enjoyful social skill, namely done through social interaction, social relationship, cooperation and collaboration (Hromek \& Roffey, 2009; Klassen \& Willoughby, 2003; Silva \& Xexéo, 2017). Furthermore, the simulation learning creates an environment which makes the students able to interact to implement knowledge and skill to the real world problem so that it improves students' learning focus, gives direct experience, is able to know the various reality and problem and makes students' learning concept which is more meaningful (Angelini, 2016; Antonoaie \& Antonoaie, 2010; Zapalska \& Brozik, 2008). Besides the simulation has more maximized the students' participation so that it makes the students learn by doing (Phillips \& Graeff, 2014).

Many educators have been use learning model such as simulation, game, or role play (Faria, 2001; Cook \& Elliott, 2016). Some researches show that in the learning process, the simulation has been used to improve various abilities in their class. The simulation can improve the students' ability to connect the abstract economical concept learnt in their lives and make their learning experience stronger (Strachan, 2015), increase their activity and their skill in their working place in business education (Seethamraju, 2011), increase their learning experience in marketing education (Lamont, 2001), increase their learning experience in accountant education (Marriott et al., 2015), increase better understanding about the concept and the principle of abstract accountant (Phillips \& Graeff, 2014), increase the conceptual understanding for science education (Kumar \& Sherwood, 2007), make the abstract concepts concrete in learning history and help tomotivate students to be able to think socially (Corbeil \& Laveault , 2011).

\section{Character Education}

Character education is the intentional intervension to promote to form all aspects in individual moral function (Berkowitz, 1999). Character education is the intentional effort to grow the goodness in the students' lives (Lickona, 1999). Character education 
is as a planned and systematic approach to increase the pride and the responsibility, the honesty and to make them good citizen (Çubukçu, 2012; Zurqoni et al., 2018b). Character education is the effort done based on the plan in social life in a whole life to create students' character (Dalmeri, 2014). Character education has function and purpose, namely to make the students become better (Lickona, 1999; Revell, 2002).

Besides the purpose of character education is to understand the moral values and changes the behavior to create positive change for the individual and finally they can take good deeds in their life (Türkkahraman, 2014; Zurqoni et al., 2018b; Lovat, 2011). In this case, character education is the planned or intentional effort to develop goodness for individuals in their lives. The existence of the character education can facilitate the individual to develop the goodness (Hakam, 2018).

School as the important institution has an important role to teach character (Arthur, 2003). The same opinion is also expressed that the development of moral character has become important aspect from education and school (Milson, 2002), and even the formal school has an active role in moral education or children character in a whole way (Helterbran, 2009). Therefore, many experts admit the school role in developing the character education and in developing the students' moral (Althof \& Berkowitz, 2006; Husu \& Tirri, 2007). Even, some researches show that most of the people believe that schools have important role in building children's character and it is natural place to build the character (Berkowitz, 1999). As, it is known that the purpose and the responsibility of educational institution included schools not only for giving knowledge but also making the students get values to make them as humans giving contribution in their moral values and influencing their character positively (Türkkahraman, 2014).

Therefore, the character education (moral education, value education) has become important part at school because it can develop the positive attitude, improve the ethics. It can also develop the pro-social attitude (Berkowitz, 2011). The program of character education is absolutely needed at school, because school becomes a part of community which cares about students (Lewis et al., 2011). The school climate which has the care can urge the social relation and emotional relation and can promote the positive interpersonal experience and can form the character (Narvaez \& Lapsley, 2008). Even the character education has become a need at school (Brannon, 2008). The development of character education has become more important to be taught in all education level (Taplin, 2002), also the elementary level and also secondary school (Baehr, 2017). Even all schools must involve the character education because school is better and condusive place to teach and to learn (Lickona, 1996).

Through education at school, character education can be integrated in the learning process (Farrelly, 1993). Character education integrated in the learning process in the classroom makes the character education effective become developed (Berkowitz \& Bier, 2005). Therefore some important characters for the students' lives can be developed by schools, especially in learning economics such as cooperation, responsibility, care, best service, honesty, help each other, and fair competition (Amri et al., 2019; Mislia et al., 2016; Zurqoni et al., 2018a; Zurqoni et al., 2018b; Komalasari \& Saripudin, 2018; Arthur, 2003; Strachan, 2015; Suyatno et al., 2019). 
Simulation activities of this study is the character of students who are developed in learning economics is closely related to economic activities. The aspect of character education in the simulation of honesty is shown through economic activities carried out in a fair manner and avoiding fraud so that the activities carried out do not cause harm to other parties. Responsibility is shown that each economic actor must be responsible for all activities carried out, because every decision taken has consequences and impacts that can be caused. Care is shown that every economic actor must have concern for fellow economic actors, consumers, employees, and including the natural and social environment when carrying out economic activities. Cooperation is shown that each economic actor must be able to cooperate with other economic actors. Help each other shows that economic actors must help one another against other economic actors, including economic actors who have not been able to develop. Providing the best service shows that every economic actor must be able to provide the best service to consumers or the public. Fair competition is shown that every economic actor must carry out economic activities by promoting fair competition and not destroying competitors or other parties.

\section{METHOD}

\section{Research Design}

This research uses descriptive quantitative research design (Creswell 2009). Quantitative by using experimental design pre test and post test. The pre-test in this research is the observation of the development of character education in the learning economics process before the simulation is applied. While the post-test in this research is the observation of the development of character education in the learning economics process by using simulation. The design is used to test the difference before and after the implementation of the simulation in developing students' character in learning economics at Senior High School. Through this design it can be seen whether or not there is a simulation effect on the development of student character education in learning economics. While the descriptive by using percentage and the category of the mean score. Learning activities in pre test that do not use simulation has been observed during three meetings with duration of 135 minutes each meeting. The simulation is implemented in three meetings with each meeting uses not more than 135 minutes. The application of simulation with this time is considered to be sufficient to discuss one economic subject matter.

\section{Participant}

The participant in this research is the students of tenth grade who are learning economics. The number of the participants is 29 students $($ male $=10)$ and has relative homogeny academic ability. The students do the simulation activity based on the instruction and the scenario which have been made.

Simulation scenarios in this research consist of: (1) rules, (2) players, (3) scenes of simulation situations. The rules in brief consist of: (1) each student can choose the role to be simulated, (2) students who have obtained the role of simulation carry out within the specified time period, (3) students are free to explore the role and interaction in 
conducting simulation, (4) when a mistakes occurs the simulation can be paused, (5) after the teacher gives suggestions and opinions on the mistakes made, the simulation activities can be resumed. Players who play as economic actors are divided into roles as buyer/consumer, seller/producer, and government. Each role of economic actors has a character, namely the role of good economic actors and bad economic actors. The situation scene simulation is briefly composed: (1) interaction or transactions between economic actors, (2) among economic actors there are transactions that use a good way, (3) there are cheats committed by unscrupulous economic actors, (4) there are economic activities that show the concern and responsibility of economic actors, (5) the existence of monopoly or oligopoly actions carried out by producers/seller, (6) actions taken by the government to control the economy (including prices), (7) there is a government action to crack down on economic actors who carry out economic activities in an unfair.

\section{Instrument}

The instrument of data collection used in this research is using observation rule and questionnaire. The observation rule is used to get the data about the simulation activity done by the development of students character education during the learning economics process. The observation rule uses Likert scale with 4 points, namely score 4 (very good), score 3 (good), score 2 (bad), and score 1 (very bad). While the questionnaire is used to get the data about students' perception about the simulation activity done. The questionnaire also uses the Likert scale with 4 points, namely score 4 (strongly agree), score 3 (agree), score 2 (disagree), and score 1 (strongly disagree).

\section{Data Analysis}

The data analysis quantitative by using experiment. There is difference if $\mathrm{p}$ value or Sig. value $(2$ tailed) $<0.05$, and there is no difference if $p$ value or Sig. value $(2$ tailed) $>$ 0.05 . Descriptive analysis is used to analyze the result of observation of the students' character in the simulation process and analyze the students' response at once. The data analysis in descriptive way in observing students' character and also students' response is devided into 4 categories in scale which is counted from the highest mean score minus the lowest mean score in 4 answer categories, so that the scale rate for each category is 0.75 . Therefore, the category in the scale for the students' character adapted from Sözer (2019) namely very bad $(1 \leq \mathrm{x} \leq 1.75)$, bad $(1.76 \leq \mathrm{x} \leq 2.25)$, good $(2.26 \leq \mathrm{x} \leq 3.25)$, and very good $(3.26 \leq x \leq 4)$. While the category in scale form for students' response adapted from Astutik\&Prahani (2018) namely not positive $(1 \leq \mathrm{x} \leq 1.75)$, less positive $(1.76 \leq \mathrm{x} \leq 2.25)$, positive $(2.26 \leq \mathrm{x} \leq 3.25)$, and very positive $(3.26 \leq \mathrm{x} \leq 4)$.

\section{FINDINGS}

\section{The Development of Character Education by Using Simulation}

The values of character education in learning economics developed uses simulation is compared with the use of another teaching strategy which has been used by the teacher before. The result of developing the character education in learning economics by using simulation is shown in the following table. 
Table 1

Development of Students' Character Education before and after of Simulation Implemented

\begin{tabular}{lllllll}
\hline & & $\mathrm{N}$ & Mean & Std. Deviation & N Gain & Sig. (2-tailed) \\
\hline $\begin{array}{l}\text { Students' character } \\
\text { education }\end{array}$ & Before & 29 & 2.990 & 0.311 & 0.28 & 0.000 \\
\cline { 2 - 7 } & After & 29 & 3.277 & 0.221 & 0.28 \\
\hline
\end{tabular}

Based on table 1, it shows that simulation implemented by the teacher in learning economics can improve the development of students' character. There is increase in the students' character development along the learning process shown from the mean score $2.990(\mathrm{SD}=0.311)$ to $3.277(\mathrm{SD}=0.221)$. Besides, the $\mathrm{Sig}$. value (2-tailed) shows the score $0.000<0.05$. The score shows that there is difference in students' character development before and after the implementation of simulation in learning economics.

Data description of students' character education values in learning economics developed by using simulation can be explained in table 2 below.

Table 2

The Observation Result of Students' Character Development by using Simulation

\begin{tabular}{lllll}
\hline \multirow{2}{*}{ Aspects developed } & $\mathrm{N}=29$ & & & \\
\cline { 2 - 5 } & Very bad & Bad & Good & Very good \\
\cline { 2 - 5 } & $\%$ & 0 & 55 & 45 \\
\hline Honesty & 0 & 0 & 66 & 34 \\
Responsibility & 0 & 0 & 59 & 41 \\
Care & 0 & 0 & 59 & 41 \\
Cooperation & 0 & 0 & 52 & 48 \\
Help each other & 0 & 7 & 48 & 45 \\
Best service & 0 & 0 & 55 & 45 \\
Fair competition & 0 & 1 & 56.29 & 42.71 \\
Total percentage & 0 & & & \\
\hline
\end{tabular}

Based on table 2, it shows that the learning economics by using simulation can develop the students' character. The score of students' character after the simulation is implemented in learning economics which shows bad (1\%), good $(56.29 \%)$, and very good $(42.71 \%)$. Overall it shows that the use of simulation in learning economics can develop the students' character with very good category (see table 1 , mean $=3.277$ ). The development of students' character in learning economics which has been good is honesty, responsibility, taking care, help each other, cooperation, and fair competition. The students' characters which still need to be improved is giving the best service.

\section{Students' Perception about Simulation}

The students' perception about the development of students' character education by using simulation in the classroom shown in the table 3 below. 
Table 3

The Student's Perception about Development of Students' Character in Learning Economics by using Simulation

\begin{tabular}{|c|c|c|c|c|c|}
\hline & $\mathrm{N}=29$ & & & & \\
\hline \multirow[t]{2}{*}{ Statement } & $\begin{array}{l}\text { Not } \\
\text { positive }\end{array}$ & $\begin{array}{l}\text { Less } \\
\text { positive }\end{array}$ & Positive & $\begin{array}{l}\text { Very } \\
\text { positive }\end{array}$ & Mean score \\
\hline & $\%$ & $\%$ & $\%$ & $\%$ & $\%$ \\
\hline $\begin{array}{l}\text { Simulation implemented by the teacher is } \\
\text { based on the reallife situation in economy } \\
\text { activity }\end{array}$ & 3.4 & 13.8 & 51.7 & 31.1 & 3.10 \\
\hline $\begin{array}{l}\text { Simulation implemented by the teacher } \\
\text { makes me feel the true situation so that it } \\
\text { can add my learning experience }\end{array}$ & 0 & 17.2 & 51.7 & 31.1 & 3.14 \\
\hline $\begin{array}{l}\text { Simulation implemented teaches the } \\
\text { character education (good values) in doing } \\
\text { important economical activity for my life }\end{array}$ & 0 & 3.4 & 44.8 & 51.8 & 3.48 \\
\hline $\begin{array}{l}\text { Simulation implemented brings up various } \\
\text { skills which are important for me }\end{array}$ & 0 & 3.4 & 79.3 & 17.3 & 3.14 \\
\hline Simulation brings up the positive attitude & 0 & 0 & 75.9 & 24.1 & 3.24 \\
\hline Total Percentage & 0.68 & 7.56 & 60.68 & 31.08 & 3.22 \\
\hline
\end{tabular}

Based on the table 3, it shows that most of the students respond well to the simulation implemented in their class shown with the number of the students who respond in very positive $(31.08 \%)$, positive $(60.68 \%)$, less positive $(7.56 \%)$, and not positive $(0.68 \%)$. Therefore, the students' perception in the table 3 shows that the simulation has been positive category $($ mean $=3.22$ ) to teach character education in doing the important economical activity for the students' life.

\section{DISCUSSION}

The result of this research is based on the observation which has been done shows that the simulation implemented gives the effect for the development of students' character education in learning economics at school. The effect is shown from the existence of the difference in developing students' character education before and after the simulation implementation. The result is supports what has been expressed by Chowdhury (2016) states that the teaching techniques included the simulation can be implemented by the teacher to develop students' moral value and students' character. The result of this research shows that good character for the students in the economics field can be developed through simulation. The result that the simulation used can teach students how to carry out economic activities in good ways, and show students that economic activities that are carried out in a bad ways must be avoided. The simulation also revealed the effects that could result from decisions taken by economic actors in carrying out their economic activities. So the results of this research not only show that simulation can develop good character education for students in economics, but simulation can also show the consequences of decisions taken when students carry out economic activities in a bad way. The result of the research also shows the suitability with result shown by Hromek \& Roffey (2009); Tingstrom et al. (2006) that show the 
simulation can be used to develop empathy, pro social skill, and the improvement of students' behavior. The result of this research is also supports the statement of Beckem \& Watkins (2012) which shows that the simulation implementation in learning can develop the ethic behavior and students' responsibility.

The result of the research is also in line with the statement expressed by Silva \&Xexéo (2017); Zapata-Tamayo \& Zapata-Jaramillo (2015); Zapata-Tamayo et al (2017) who state that learning simulation implemented by teacher can develop the students' ability in cooperation and create social condition to help each other among students. Besides, the result of the research is also in line with the research done by Phillips \&Graeff (2014); Gremler et al (2000) that simulation can improve more positive attitude and students' self confidence, and students' cooperation. It can also improve to develop the human's behavior such as respect each other and care others, improve self confidence and cooperation (Srinivasan, 2005). Therefore, the result of the research confirms that good development of students' character through the learning process in the economics field to become very important to be able to be implemented sustainably.

The result from of the questionnaire about the students' perception which shows that the simulation implemented can teach character education (good values) in doing the economical activity which is important for the students' lives. The students feel that the simulation implemented in the class can express the various life skills which are important for the humans'lives. Based on the results of the observation, the teacher can teach the students about good behavior in doing the economical activities and teaches the students about bad economical behavior at once that must be left in the economical activity. So that the development of character education in learning economics through simulation can help the students to become better people. The results indicate that teacher during the learning economics process must be able to show students how good economic behavior and bad economic behavior should be abandoned by students in their economic activities. The teacher not only shows good economic activity, but also shows bad economic activity in the simulation. These results support has been revealed by Lickona (1999); Revell (2002) about character education can help students become good people. It is not only for the sake of the goodness of the students themselves but also it is for other people and the environment (Peterson \& Seligman, 2004; Dianti, 2014; Francis, 1962; Gunawan, 2012; Türkkahraman, 2014; Zurqoni et al., 2018b; Lovat, 2011; Zubaedi, 2012). As one of the examples, it is the way how the students simulate a situation which shows the attitude to help each other in fulfilling their economic needs (Strachan, 2015). Therefore, the result of the research is in line with the statement stated by Milson (2002) that the social study included in economics field has relation with the character education. The development of character education becomes an important part for learning economics at school.

Based on students' perception, the result of the research shows that the simulation in learning economics can implement the situation of real daily life, which have ever happened to them and the things which have never happened to the students in economical activity to be brought and performed in the class. The result confirms what has been proven by previous research that through simulations of real world activities 
can be displayed in the classroom (Ruiz et al., 2014; McKeachie, 1986; Merideth \& Yaseen, 2000). The simulation activity done is based on the daily economical activity or the economical activity in students' daily activity, or economical activity which has ever happened and become the society conversation. So that the simulation activity implemented make the students can feel the economical activity as if it were the real situation. The situation of the real world brought in the class is the economical activity whether it is good or bad economical activity, namely by giving role to the students as the good or bad economical actor (Gillentine \& Schulz, 2001).

Some real economical activities performed in the class is the economical activity which contains character values such as honesty, responsibility, cooperation, fair competition, care, help each other. Economical activities that have been practiced in simulation are real economic activities that have occurred, so that the simulated economic activities can provide very important experiences for students in carrying out their economic activities. This result confirms that through the implementation of real life into the class, the students get the better learning experience in the economics field which may be done or may not be done (Haslip \& Haslip, 2013; Strachan, 2015; Gillentine \& Schulz, 2001; Elam, \& Spotts, 2004; Seethamraju, 2011; Marriott et al., 2015; Guerrero, 2007). Thus the result shows that the use simulation activity that involves the students to implement the real-life in economical activity in the class that they can add students' learning experience in the economics field to be better. Students gain experience in carrying out economic activities using good ways and experience when carrying out economic activities in a bad way, and economic activities carried out in bad ways have legal consequences.

However, the results of this study still need further research, especially those relating to the influence of the development of character education for student behavior in longterm economic activities. The learning process uses simulation that practice economic activities in accordance with real life, need further research to see the impact on student behavior in daily life in carrying out economic activities. Further research is needed to determine the impact of learning by using simulation that practice good economic activities and bad economic activities on the economic behavior of students in the future or after they are adults.

\section{CONCLUSION}

This study confirms that there is the effect of using simulation in the development of students' character at school, especially for in learning economics. The results of this research indicate that the development of student character education in learning economics can be improved through the use of simulation. The result shows that there is difference in the development of students' character before and after the simulation implementation in learning economics (Sig. value $=0.000)$. The development of character education through the learning becomes very important to be able to be implemented by the teacher at school. The simulation use in learning economics can give contribution for the development of students' character in economics field. The development of students' character based on observations during the learning process using simulation shows very good category (mean= 3.277), and from students' 
perceptions shows the positive category (mean= 3.22). The learning economics by using simulation contains the very important character for the students' daily economical life, such as honesty, responsibility, care, help each other, and other good behaviors. The character education and economical education have the same purposes namely to make the students as humans or good economical players who are not only do good things for themselves but also for others. Therefore, the development of character education in learning economics to do it sustainably by using simulation.

\section{ACKNOWLEDGMENT}

Thanks is presented to the Directorate of Research and Community Service, Ministry of Research, Technology and Higher Education the Republic of Indonesia which gives its support as well as the research fund in the form of doctoral dissertation research.

\section{REFERENCES}

Almerico, G. M. (2014). Building character through literacy with children's literature. Research in Higher Education Journal, 26, 1-13.

Althof, W., \& Berkowitz, M. W. (2006). Moral education and character education: Their relationship and roles in citizenship education. Journal of Moral Education, 35(4), 495-518.

Amri, F. (2018). Mengembangkan karakter dalam pembelajaran ekonomi. Seminar Nasional Multidisiplin UNWAHA, 29 September 2018, 110-124.

Amri, F., Djatmika, E. T., Wahyono, H., \& Widjaja, S. U. M. (2019). Pengembangan sintaks simulasi dalam pembelajaran ekonomi berorientasi pada pendidikan karakter. Jurnal Pendidikan Ilmu Sosial, 28(1), 61-76.

Angelini, M. L. (2016). Integration of the pedagogical models "simulation" and "flipped classroom" in teacher instruction. SAGE Open, January-March, 1-8.

Antonoaie, C., \& Antonoaie, N. (2010). Computer-based simulations. Bulletin of the Transylvania University of Brasov, 3(52), 169-172.

Arthur, J. (2003). Education with character: The moral economy of schooling. London: Routledge Falmer.

Arthur, J., \& Carr, D. (2013). Character in learning for life: A virtue-ethical rationale for recent research on moral and values education. J of Beliefs \& Values, 34(1), 26-35.

Arweck, E., Nesbitt, E., \& Jackson, R. (2005). Common values for the common school? Using two values education programmes to promote 'spiritual and moral development'. Journal of Moral Education, 34(3), 325-342.

Astutik, S., \& Prahani, B. K. (2018). The practicality and effectiveness of collaborative creativity learning (CCL) model by using PhET simulation to increase students' scientific creativity. International Journal of Instruction, 11(4), 409-424. 
Baehr, J. (2017). The varieties of character and some implications for character education. J Youth Adolescence, 46(6), 1153-1161. doi: 10.1007/s10964-017-0654-z.

Bahri, S. (2015). Implementasi pendidikan karakter dalam mengatasi krisis moral di sekolah. Ta'allum, 3(1), 57-76.

Beckem, J. M., \& Watkins, M. (2012). Bringing life to learning: Immersive experiential learning simulations for online and blended courses. Journal of Asynchronous Learning Networks, 16(5), 61-71.

Beldağ, A. (2016). Values education research trends in Turkey: A content analysis. Journal of Education and Training Studies, 4(5), 101-112.

Berkowitz, M. W. (1999). Obstacles to teacher training in character education. Action in Teacher Education, 20(4), 1-10.

Berkowitz, M. W. (2011). What works in values education? International Journal of Educational Research, 50(3), 153-158.

Berkowitz, M. W., \& Bier, M. C. (2005). What works in character education: A research-driven guide for educators. Washington: Character Education Partnership.

Betts, K., Lewis, M., Dressler, A., \& Svensson, L. (2009). Optimizing learning simulation to support a quinary career development model. Asia-Pacific Journal of Cooperative Education, 10(2), 99-119.

Brannon, D. (2008). Character education: It's a joint responsibility. Kappa Delta Pi Record, 44(2), 62-65.

Chowdhury, M. (2016). Emphasizing morals, values, ethics, and character education in science education and science teaching. The Malaysian Online J of Edu Sci, 4(2), 1-16.

Cook, S., \& Elliott, C. (2016). Innovations in economics education: An introduction to economic and econometric tools for teaching and learning. Cogent Economics \& Finance, 4, 1-3.

Corbeil, P., \& Laveault, D. (2011). Validity of a simulation game as a method for history teaching. Simulation \& Gaming, 42(4), 462-475.

Creswell, J. W. (2009). Research design: Qualitative, quantitative, and mixed methods approaches. California: SAGE Publications.

Çubukçu, Z. (2012). The effect of hidden curriculum on character education process of primary school students. Educational Sciences: Theory \& Practice, 12(2), 1526-1534.

Dalmeri. (2014). Pendidikan untuk pengembangan karakter (telaah terhadap gagasan Thomas Lickona dalam educating for character). Al-Ulum, 14(1), 269-288. 
DeNeve, K. M., \& Heppner, M. J. (1997). Role play simulations: The assessment of an active learning technique and comparisons with traditional lectures. Innovative Higher Education, 21(3), 231-246.

Dianti, P. (2014). Integrasi pendidikan karakter dalam pembelajaran pendidikan kewarganegaraan untuk mengembangkan karakter siswa. Jurnal Pendidikan Ilmu Sosial, 23(1),58-68.

Elam, E. L.R., \& Spotts, H. E. (2004). Achieving marketing curriculum integration: A live case study approach. Journal of Marketing Education, 26(1), 50-65.

Faria, A. J. (2001). The changing nature of business simulation gaming research: A brief history. Simulation \& Gaming, 32(1), 97-110.

Farrelly, T. M. (1993). A new approach to moral education: The integrated character education model. Journal of Correctional Education, 44(2), 76-82.

Francis, E. F. (1962). Fundamentals of character education. School Rev, 70(3), 345-357.

Ganesh, G., \& Sun, Q. (2009). Using simulations in the undergraduate marketing capstone case course. Marketing Education Review, 19(1), 7-16.

Gillentine, A., \& Schulz, J. (2001). Marketing the fantasy football league: Utilization of simulation to enhance sport marketing concepts. J of Marketing Edu, 23(3), 178-186.

Gremler, D. D., Hoffman, K, D., Keaveney, S. M., \& Wright, L. K. (2000). Experiential learning exercises in services marketing courses. J of Marketing Edu, 22(1), 35-44.

Guerrero, K. (2007). A world bazaar: Learning about community, geography, and economics. Social Studies and the Young Learner, 19(4), 4-6.

Gunawan, H. (2012). Pendidikan karakter (konsep dan implementasi). Bandung: Alfabeta.

Hakam, K. A. (2018). Tradition of value education implementation in Indonesian primary schools. Journal of Social Studies Education Research, 9(4), 295-318.

Haslip, M. L., \& Haslip, M. J. (2013). From Malaysia to America: Community-based character education for children and youth. Childhood Education, 89(5), 296-302.

Helterbran, V. R. (2009). Linking character education and global understanding through children's. Kappa Delta Pi Record, 45(2), 69-73.

Ho, H-Z., Lam, Y. M., \& Yeh, K-H. (2013). Character education in Taiwan: A reflection of historical shifts in sociocultural contexts. Childhood Edu, 89(6), 362-367.

Hromek, R., \& Roffey, S. (2009). Promoting social and emotional learning with games "it's fun and we learn things". Simulation \& Gaming, 40(5), 626-644. 
Husu, J., \& Tirri, K. (2007). Developing whole school pedagogical values: A case of going through the ethos of "good schooling'. Teaching and Teacher Edu, 23, 390-401.

Klassen, K. J., \& Willoughby, K. A. (2003). In-class simulation games: Assessing student learning. Journal of Information Technology Education, 2, 1-13.

Komalasari, K., \& Saripudin, D. (2018). The influence of living values education-based civic education textbook on student's character formation. Int J of Ins, 11(1), 395-410.

Kuh, G. D., \& Umbach, P. D. (2004). College and character: Insights from the national survey of student engagement. New Directions for Institutional Research, 122, 37-54.

Kumar, D. D., \& Sherwood, R. D. (2007). Effect of a problem based simulation on the conceptual understanding of undergraduate science education students. Journal of Science Education and Technology, 16(3), 239-246.

Lamont, L. M. (2001). Enhancing student and team learning with interactive marketing simulations. Marketing Education Review, 11(1), 45-55.

Lee, C-M. (2009). 'The planning, implementation and evaluation of a character-based school culture project in Taiwan'. Journal of Moral Education, 38(2), 165-184.

Lewis, S. V., Robinson, E. H., \& Hays, B. G. (2011). Implementing an authentic character education curriculum. Childhood Education, 87(4), 227-231.

Lickona, T. (1996). Eleven principles of effective character education. Journal of Moral Education, 25(1), 93-100.

Lickona, T. (1999). Character education: Seven crucial issues. Action in Teacher Education, 20(4), 77-84.

Lopes, J., Oliveira, C., Reed, L., \& Gable, R. A. (2013). Character education in Portugal. Childhood Education, 89(5), 286-289.

Lovat, T. (2011). Values education and holistic learning: Updated research perspectives. International Journal of Educational Research, 50, 148-152.

Marriott, P., Tan, S. M., \& Marriott, N. (2015). Experiential learning: A case study of the use of computerised stock market trading simulation in finance education. Accounting Education, 24(6), 480-497.

Martinson, D. L. (2003). High school students and character education it all starts at Wendy's. Journal of Educational Strategies, 77(1), 14-17.

Matchett, N. J. (2009). Cooperative learning, critical thinking, and character. Public Integrity, 12(1), 25-38.

McKeachie, W. J. (1986). Teaching tips: A guidebook for the beginning college teacher. Lexington, MA: DC. Heath \& Co. 
Merideth, R., \& Yaseen, R. (2000). Using role-play simulations to teach environmental decision making and conflict resolution techniques. Environmental Prac, 2(2), 139-145.

Milson, A. J. (2002). Introduction: Developing a comprehensive approach to character education in the social studies. The Social Studies, 93(3), 101-102.

Mislia., Mahmud, A., \& Manda, D. (2016). The implementation of character education through scout activities. International Education Studies, 9(6), 130-138.

Narvaez, D., \& Lapsley, D. K. (2008). Teaching moral character: Two alternatives for teacher education. The Teacher Educator, 43(2), 156-172.

Novianti, N. (2017). Teaching character education to college students using bildungsroman's. International Journal of Instruction, 10(4), 254-272.

Nurdin, E. S. (2015). The policies on civic education in developing national character in Indonesia. International Education Studies, 8(8), 199-209.

Peterson, C., \& Seligman, M. E. P. (2004). Character strengths and virtues: A handbook and classification. New York, NY: Oxford University Press, Inc.

Phillips, M. E., \& Graeff, T. R. (2014). Using an in-class simulation in the first accounting class: Moving from surface to deep learning. Journal of Education for Business, 89(5), 241-247.

Revell, L. (2002). Children's responses to character education. Edu Stu, 28(4), 421-431.

Revell, L., \& Arthur, J. (2007). Character education in schools and the education of teachers. Journal of Moral Education, 36(1), 79-92.

Roux, I., \& Steyn, B. (2007). Experiential learning and critical reflection as a tool for transfer of business knowledge: An empirical case study of a start-up simulation intervention for nascent entrepreneurs. SAJEMS NS, 10(3), 330-347.

Ruiz, S., Aguado, C., \& Moreno, R. (2014). Educational simulation in practice: A teaching experience using a flight simulator. J of Tech and Sci Edu, 4(3), 181-200.

Scalise, K., Timms, M., Moorjani, A., Clark, L., Holtermann, K., \& Irvin, P. S. (2011). Student learning in science simulations: Design features that promote learning gains. Journal of Research in Science Teaching, 48(9), 1050-1078.

Seel, N. M., \& Blumschein, P. (2009). Modeling and simulation in learning and instruction: A theoretical perspective. In P. Blumschein, W. Hung, D. Jonassen, \& J. Strobel (Eds.). Model-based approaches to learning: Using systems models and simulations to improve understanding and problem solving in complex domains (pp 315). Rotterdam: Sense Publishers. 
Seethamraju, R. (2011). Enhancing student learning of enterprise integration and business process orientation through an ERP business simulation game. Journal of Information Systems Education, 22(1), 19-29.

Silva, V., \& Xexéo, G. (2017). Money basket: A classroom game about the basic mechanics of the stock exchange market. Developments in Business Simulation and Experiential Learning, 44, 288-289.

Sözer, M. A. (2019). Effective teacher immediacy behaviors based on students' perceptions. Universal Journal of Educational Research, 7(2), 387-393.

Srinivasan, M. V. (2005). Teaching economics in India: A teacher's handbook. New Delhi: Department of Education in Social Sciences.

Strachan, S. L. (2015). Kindergarten students' social studies and content literacy learning from interactive read-alouds. The J of Social Studies Research, 39, 207-223.

Suyatno., Jumintono., Pambudi, D. I., Mardati, A., \& Wantini. (2019). Strategy of values education in the Indonesian education system. International Journal of Instruction, 12(1), 607-624.

Taplin, M. (2002). Can we, should we, and do we integrate values education into adult distance education? opinions of stakeholders at the open university of Hong Kong. International Journal of Lifelong Education, 21(2), 142-161.

Tatto, M. T., Arellano, L. A., Uribe, M. T., Varela, A. L., \& Rodriguez, M. (2001). Examining Mexico's values education in a globally dynamic context. Journal of Moral Education, 30(2), 173-198.

Thornberg, R., \& Oguz, E. (2016). Moral and citizenship educational goals in values education: A cross-cultural study of Swedish and Turkish student teachers' preferences. Teaching and Teacher Education, 55, 110-121.

Tingstrom, D. H., Sterling-Turner, H. E., \& Wilczynski, S. M. (2006). The good behavior game: 1969-2002. Behavior Modification, 30(2),225-253.

Türkkahraman, M. (2014). Social values and value education. Procedia-Social and Behavioral Sciences, 116, 633-638.

Zapalska, A. M., \& Brozik, D. (2008). A model for developing and evaluating games and simulations in business and economic education. Zb. rad. Ekon.fak. Rij, 26(2), 345368.

Zapata-Tamayo, S., \& Zapata-Jaramillo, C.M. (2015). Building social communities as a foundation for entrepreneurship: A game-based approach. Developments in Business Simulation and Experiential Learning, 42, 117-123. 
Zapata-Tamayo, J. S., Zapata-Jaramillo, C. M., \& Betín-Montes, M. E. (2017). Learning business process improvement by using a game. Developments in business simulation and experiential learning, 44, 210-216.

Zubaedi. (2012). Desain pendidikan karakter (konsepsi dan aplikasinya dalam lembaga pendidikan). Jakarta: Kencana Prenada Media Group.

Zurqoni., Retnawati, H., Apino, E., \& Anazifa, R. D. (2018a). Impact of character education implementation: A goal-free evaluation. Problems of Education in the 21st Century, 76(6), 881-899.

Zurqoni, Retnawati, H., Arlinwibowo, J., \& Apino, E. (2018b). Strategy and implementation of character education in senior high schools and vocational high schools. Journal of Social Studies Education Research, 9(3), 370-397. 